Marine Chemistry

Vol. 88, Issues 1-2, August 2004, Pages 53-60

http://dx.doi.org/10.1016/j.marchem.2004.03.004

(c) 2004 Elsevier B.V. All rights reserved
Archimer, archive institutionnelle de l'Ifremer http://www.ifremer.fr/docelec/

\title{
Spectrophotometric Winkler determination of dissolved oxygen: re- examination of critical factors and reliability
}

\author{
Thierry Labasque ${ }^{\mathrm{a},{ }^{\star}}$, Christian Chaumery $^{\mathrm{b}}$, Alain Aminot $^{\mathrm{c}}$ and Gilles Kergoat ${ }^{\mathrm{a}}$
}

\author{
a Service hydrographique et océanographique de la marine, Etablissement principal, 13 rue du \\ Chatellier, B.P. 30316, 29603, Brest Cedex, France \\ ${ }^{\mathrm{b}}$ Institut universitaire européen de la mer, Technopole Brest-Iroise, Laboratoire de chimie marine, \\ Place Nicolas Copernic, 29280 Plouzané, France \\ ${ }^{\mathrm{C}}$ IFREMER, Centre de Brest, Direction de l'environnement et de l'aménagement littoral, Département \\ écologie côtière., B.P. 70, 29280 Plouzané, France
}

*: Corresponding author : Tel.: +33-2-23-23-57-49; fax: +33-2-23-23-60-90; Thierry.labasque@univ-rennes1.fr

\begin{abstract}
:
The spectrophotometric iodine measurement for oxygen determination by the Winkler method is reexamined for theoretical and operational aspects. It is shown that the selection of an isobestic point for measuring the mixture of iodine and tri-iodide in the solution enhances reliability. The wavelength value of $466 \mathrm{~nm}$ was selected after a spectrum study. Then, performances are assessed by mean of statistical approach based on repeated standardization curves at the isobestic point compared with other wavelengths. At $466 \mathrm{~nm}$, the method is linear up to about $1000 \mu \mathrm{mol} \mathrm{kg}-1$ of O2. Optimization and validation of the spectrophotometric method is realized through a robustness study based on factors that may alter the results (temperature, reagent volumes, storage time). Temperature is the only factor that exerts a significant influence on the absorbance $\left(0.5 \%\right.$ per $\left.{ }^{\circ} \mathrm{C}\right)$, hence samples and standards should be kept at the same temperature within $\pm 1^{\circ} \mathrm{C}$.
\end{abstract}

Precision was estimated over a 10-day period. The standard deviation was $0.45 \%$ for inter-sample repeatability and $0.73 \%$ for reproducibility near $250 \mu \mathrm{mol} \mathrm{kg}-1$. The repeatability of 12 samples taken at the same immersion was around $0.12 \%$. The detection limit, determined from standardization curves, is $<2 \mu \mathrm{mol} \mathrm{kg}-1$. Accuracy was verified with $\mathrm{O} 2$ saturated seawater and found to be within the precision confidence interval.

The method can be applied to the determination of dissolved oxygen in fresh or seawater samples, suboxic, or waters supersaturated in dissolved oxygen. It is suggested as being a suitable alternative to titration in most applications of the Winkler determination of dissolved oxygen.

Keywords: Dissolved oxygen; Spectrophotometry; Sea water; Isobestic point 


\section{INTRODUCTION}

The Winkler iodometric determination is still considered as the reference method for the measurement of dissolved oxygen (DO) in waters (AFNOR, 1999) and for calibration of in situ probes (Millard, 1991). In this method, divalent manganese, added to the sample and precipitated by an alkaline-iodide reagent is oxidized (into $\mathrm{Mn}$ (III) and (IV)) by dissolved molecular oxygen. Under subsequent acidification, $\mathrm{Mn}$ (III) and (IV) oxidize iodide into iodine. Iodine is usually titrated by thiosulfate but can also be measured by spectrophotometry.

Spectrophotometry has been used as an improvement of the end-point detection compared with the visual starch technique (e.g. Bryan et al., 1976). However, its use for direct iodine measurement instead of the classical titration is not widespread in spite of several advantages (Morel, 1965; Ashton and Twinch, 1985; Roland et al. 1999). First, no unstable solution is used and less frequent calibration is required. Standardization of thiosulfate in the titration technique was previously identified as the most common source of inaccuracy (Carritt and Carpenter, 1966; Pai et al., 1993). Second, volatilization of iodine, a major source of error (Green and Carritt, 1966; Aminot, 1988; Pai et al., 1993), is almost totally eliminated by using a pump and a flow cell (Pai et al., 1993). Finally, the analytical throughput, which is much greater than for titration, is well adapted to deep oceanic stations where large numbers of samples have to be treated simultaneously. Overall, sample handling is minimized, making the analysis easier for an unskilled person and reducing the human factor on reliability. Additionally, the cost per analysis is reduced (Morel, 1965; Roland et al., 1999).

One of the main reasons for the limited adoption of the spectrophotometric method may be the inconsistency of measuring wavelengths found in literature, along with rare and unclear justification for the selected value. Intense absorption of UV and visible light in the solution resulting from Winkler reactions happens because iodine is partly free and partly combined with residual iodide as tri-iodide complex. The spectra of these two forms are quite different. Cluster and Natelson (1949), then Broenkow and Cline (1966), selected the second tri-iodide maximum $(352 \mathrm{~nm})$ in order to measure very low dissolved oxygen concentrations (0 $\left.50 \mu \mathrm{mol} \mathrm{kg}{ }^{-1}\right)$. Ashton and Twinch (1985) and Roland et al. (1999) relied on the value used by Mackereth et al. (1978), $430 \mathrm{~nm}$. The latter referred to Duval et al. (1974), although these worked at 287.5 (maximum absorbance of acidified iodine solution), which implied a 20 -fold dilution of the sample. Pai et al. (1993) used $456 \mathrm{~nm}$ for various reasons including that "the molar absorptivities of molecular iodine and the tri-iodide ion are similar at 450-460 nm". Only Morel (1965) clearly selected a working wavelength $(466 \mathrm{~nm})$ after a study of the free and complexed iodine spectra undertaken to identify isobestic points (wavelengths at which molar absorptivities are identical). This criterion, apparently ignored by most authors, is a key factor for reliable spectrophotometric Winkler DO determination.

The aim of the present work was to re-examine the spectrophotometric measurement of iodine applied to the Winkler method. This included verification of the isobestic point wavelengths, selection of the optimum one, checks on potential factors that may alter the results (e.g. temperature, reagent volume, conservation time) and determination of precision and accuracy. Standardization was statistically validated and a comparison with the traditional thiosulfate titration is presented. 


\section{MATERIAL AND METHODS}

The optimized version of the Winkler method, as described by Carpenter (1965b), was used, with particular attention to reagent concentrations.

Reagent one (R1) is the manganese chloride solution $\left(3 \mathrm{~mol} \mathrm{~L}^{-1}\right)$. Reagent two (R2) is the alkaline-iodide solution ( $\left.\mathrm{NaOH} 8 \mathrm{~mol} \mathrm{~L}^{-1}, \mathrm{NaI} 4 \mathrm{~mol} \mathrm{~L}^{-1}\right)$. Reagent three (R3) is the sulphuric acid solution $\left(10 \mathrm{~mol} \mathrm{~L}^{-1}\right)$. Overall reagent concentrations are $6 \mathrm{ml} \mathrm{L}{ }^{-1}$ of sample. Standardization is made using a $5.95 \mathrm{mmol} \mathrm{L}^{-1}$ potassium iodate solution.

Sample flasks (narrow mouth ground glass stopper bottles, $146 \pm 1 \mathrm{~mL}$ ) were filled using a plastic tube fitted onto the sampling bottle tap end and inserted into the sample flask, almost to the bottom. The flask is filled and overflowed by at least one bottle volume. $\mathrm{R} 1$ and $\mathrm{R} 2$ reagents $(0.9 \mathrm{~mL}$ each) were immediately added to the sample, the stopper placed and the flask shaken. The flask is closed by the stopper after the introduction of reagent R1 and R2 (which are denser than the water), in order to displace the small volume of water of the neck of the bottle, which is in contact with atmosphere in order to prevent contamination by bubbles of air. The flask was again shaken a few minutes later. This procedure follows Carrit and Carpenter's (1966) recommendations.

Within $3 \mathrm{~h}$ of collection, R3 was added $(0.9 \mathrm{~mL})$, then absorbance was measured within 5 min, using a computerized Perkin Elmer Lambda 16 spectrophotometer (passband $1 \mathrm{~nm}$, resolution $10^{-4} \mathrm{AU}$ ), equipped with a $1 \mathrm{~cm}$ optical path flow cell fed by a peristaltic pump $\left(10 \mathrm{~mL} \mathrm{~min}^{-1}\right)$.

Standardization relied on the preparation of $\mathrm{I}_{2}+\mathrm{I}_{3}{ }^{-}$solutions by oxidation of iodide with iodate. Fifty milliliters of demineralized water was introduced in $100 \mathrm{~mL}$ volumetric flasks, then $0.6 \mathrm{~mL}$ of $\mathrm{R} 3,0.6 \mathrm{~mL}$ of $\mathrm{R} 2$ and $0.6 \mathrm{~mL}$ of $\mathrm{R} 1$ were successively added with intermediate mixing. Accurately known volumes of the standard potassium iodate solution were finally added. One mole of iodate produces three moles of iodine, equivalent to $3 / 2$ moles of DO in samples. Therefore, standardization directly relates absorbance as a function of oxygen concentration. Relationships were fitted using standard software to obtain the slope $a$. The intercept corresponds to the reagent blank.

Dissolved oxygen concentration was computed as follows:

$$
\mathrm{C}=\left[\left(\mathrm{A}_{\mathrm{s}}-\mathrm{A}_{\mathrm{b}}\right) / a\right] \cdot\left[\left(\mathrm{V}_{\mathrm{f}} /\left(\mathrm{V}_{\mathrm{f}}-\mathrm{V}_{\mathrm{R}}\right)\right] \cdot 1 / \rho-\mathrm{O}_{2 \text { reagent }}\right.
$$

Where $\mathrm{C}=$ dissolved oxygen concentration $\left(\mu \mathrm{mol} \mathrm{kg} \mathrm{kg}^{-1}\right) ; \mathrm{A}_{\mathrm{s}}=$ cell blank corrected absorbance for the sample; $A_{b}=$ absorbance for the blank; $a$ : standardization curve slope $\left(A U \mu \mathrm{mol}^{-1} \mathrm{~L}\right), \mathrm{V}_{\mathrm{f}}$ : sample volume $(\mathrm{mL}) ; \mathrm{V}_{\mathrm{R}}$ : total reagent volume, $\mathrm{R} 1+\mathrm{R} 2(\mathrm{~mL}) ; \mathrm{O}_{2 \text { reagent }}=\mathrm{DO}$ added by the reagents, $0.5 \mu \mathrm{mol} \mathrm{L}^{-1}$ (Murray et al., 1968); $\rho$ : water density in $\mathrm{kg} \mathrm{dm}^{-3}$.

The stability of $a$ and $A_{b}$ is systematically checked for each analytical series.

\section{THEORY}

Iodine formed during the Winkler reactions is present under the free form $\mathrm{I}_{2}$ and the tri-iodide form $\mathrm{I}_{3}^{-}$according to equilibrium (1)

$$
\mathrm{I}_{2}+\mathrm{I}^{-}=\mathrm{I}_{3}^{-}
$$

$\mathrm{K}=725$ at $25^{\circ} \mathrm{C}$ (Burger and Liebhafsky, 1973). 
The proportions of iodine and tri-iodide depend on the initial concentration of iodide, the concentration of dissolved oxygen and temperature. Since iodide is generally in large excess, proportions of $\mathrm{I}_{2}$ and $\mathrm{I}_{3}{ }^{-}$depend only slightly on DO concentration and are roughly proportional to iodide concentration. With the optimized Carpenter's reagents, tri-iodide ion comprises about $95 \%$ of total iodine generated by dissolved oxygen. With reagents containing less iodide a smaller proportion of iodine is complexed, increasing the risk of volatilization.

Although only $I_{2}$ results from the Winkler reaction, spectrophotometric measurements depend on the two species $\mathrm{I}_{2}$ and $\mathrm{I}_{3}{ }^{-}$. Total absorbance of the solution $\left(A_{T}\right)$ is the sum of the absorbances of iodine and tri-iodide, respectively $A_{I 2}$ and $A_{I 3}$ :

$$
A_{T}=A_{12}+A_{13}=\varepsilon_{12} C_{12}+\varepsilon_{13} C_{13},
$$

where $\varepsilon$ and $\mathrm{C}$ denote molar absorptivity and concentrations of the species, respectively. For DO determination, the important quantity to be determined is total iodine, i.e. $\left(\mathrm{C}_{\mathrm{I} 2}+\mathrm{C}_{\mathrm{I}}\right)$. Clearly, $\mathrm{A}_{\mathrm{T}}$ will be proportional to this amount only in two cases. Either if the molar absorptivities of the two compounds are equal $\left(\varepsilon_{\mathrm{I} 2}=\varepsilon_{13}\right)$, or if the contribution of $\mathrm{I}_{2}$ is negligible compared with $\mathrm{I}_{3}{ }^{-}$, i.e. both if a large excess of iodide is present in the solution and if $\varepsilon_{\mathrm{I} 2}<\varepsilon_{\mathrm{I} 3}$. Selecting the wavelength of an isobestic point $\left(\varepsilon_{\mathrm{I} 2}=\varepsilon_{\mathrm{I} 3}\right)$ for iodine determination is therefore the most simple way to obtain reliable DO results.

\section{RESULTS AND DISCUSSION}

\subsection{Wavelength selection}

In order to study iodine and iodide spectra, pure solutions of these species were prepared by diluting a $10^{-3} \mathrm{~mol} \mathrm{~L}^{-1}$ iodine solution on the one hand with sulphuric acid $\left(0.05 \mathrm{~mol} \mathrm{~L}^{-1}\right)$ and on the other hand with a $0.1 \mathrm{~mol} \mathrm{~L}^{-1}$ iodide potassium solution in sulphuric acid $\left(0.05 \mathrm{~mol} \mathrm{~L}^{-1}\right)$.

Figure 1 presents the spectra of pure $\mathrm{I}_{2}$ and $\mathrm{I}_{3}{ }^{-}$from 400 to $600 \mathrm{~nm}$. Two intersection (isobestic) points $\left(\varepsilon_{\mathrm{I} 2}=\varepsilon_{\mathrm{I} 3}\right)$ are identified, one at $466 \mathrm{~nm}$ and another in the range $580-590 \mathrm{~nm}$. The first point confirms exactly Morel (1965) results. The second point, which is more imprecise due to the lower absorbance, occurs in a similar range to that reported by Morel (1965) i.e. 550-560 nm. The difference may result from the difficulty for preparing and handling pure solutions of the $I_{2}$ forms, because of the volatilization and oxidation processes which can be slowed, but not totally stopped.

Due to the sharply increasing absorption of $\mathrm{I}_{3}{ }^{-}$and decreasing absorption of $\mathrm{I}_{2}$ below $466 \mathrm{~nm}$, sensitivity increases with decreasing wavelength. At $460 \mathrm{~nm}$, Awtrey and Connick (1951) measured molar absorptivities around 975 and $746 \mathrm{~mol}^{-1} \mathrm{~L} \mathrm{~cm}^{-1}$ for $\mathrm{I}_{3}{ }^{-}$and $\mathrm{I}_{2}$, respectively. The molar absorptivities we measured at $25^{\circ} \mathrm{C}$ at the isobestic points were $\varepsilon^{466} \approx 740 \mathrm{~mol}^{-1} \mathrm{~L} \mathrm{~cm}^{-1}$ and $\varepsilon^{580} \approx 79 \mathrm{~mol}^{-1} \mathrm{~L} \mathrm{~cm}^{-1}$. The wavelength $466 \mathrm{~nm}$ was preferable since it provides adequate sensitivity of the DO determination for concentrations usually encountered in natural waters. For instance, saturated seawater at $15^{\circ} \mathrm{C}$ leads to an absorbance of $\approx 0.4$ in $1 \mathrm{~cm}$ light path cells.

\subsection{Standardization : linearity and precision}

Standardization was studied on $\mathrm{I}_{2}+\mathrm{I}_{3}{ }^{-}$solutions obtained by oxidation of iodide with iodate in a range equivalent to $0-892 \mu \mathrm{mol} / \mathrm{L}\left(0-20 \mathrm{~mL} \mathrm{~L}^{-1}\right)$ dissolved oxygen. Standardization was performed at our selected wavelength, $466 \mathrm{~nm}$, and at 


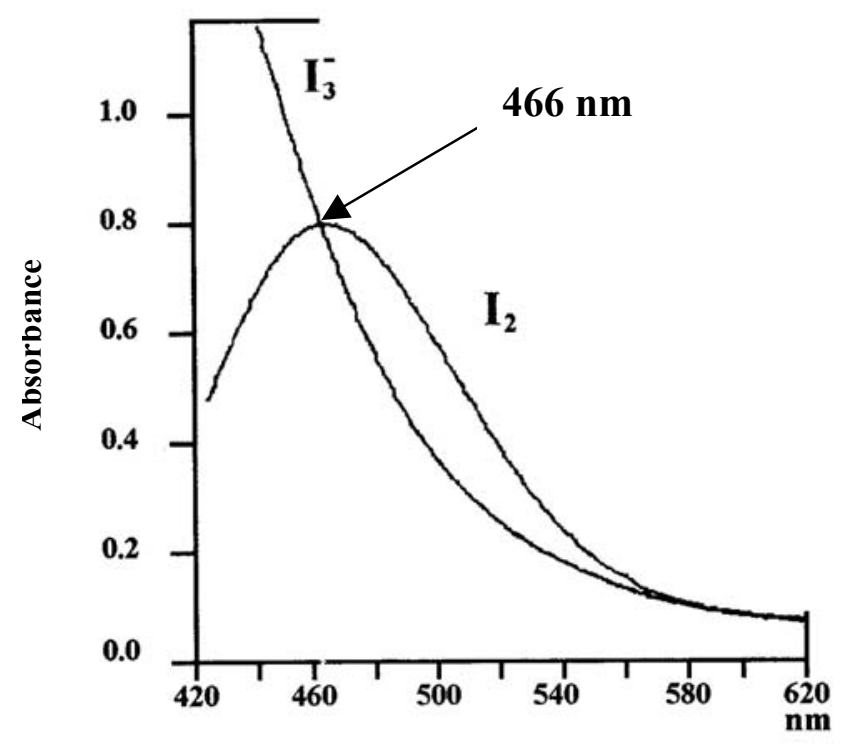

Figure 1. Spectrum of pure solutions of $I_{2}$ and $I_{3}{ }^{-}$in distilled water.

two other wavelengths currently used in the literature, 430 and $456 \mathrm{~nm}$, for comparison. Standard curves were repeated six times. Linearity, sensitivity, uncertainty, detection and quantification limits were studied (Table 1). The linearity test (Analytical Methods Committee, 1994), confirmed that optimal results are obtained at the isobestic point, $466 \mathrm{~nm}$. The Beer-Lambert law is followed up to the maximum concentration checked, $\approx 900 \mu \mathrm{mol} \mathrm{L}^{-1}$ of $\mathrm{O}_{2}$. At $430 \mathrm{~nm}$, Mackereth et al. (1978) and Roland et al. (1999) mentioned non-linearity above 12-13 $\mathrm{mg} \mathrm{L}^{-1}$ $\left(375 \mu \mathrm{mol} \mathrm{kg}{ }^{-1}\right)$ and erratic values above $24 \mathrm{mg} \mathrm{L}^{-1}\left(750 \mu \mathrm{mol} \mathrm{kg}{ }^{-1}\right)$. At the isobestic point $466 \mathrm{~nm}$, the slope of the standardization curve, which expresses the sensitivity of the method in $1 \mathrm{~cm}$ light path cells (Table 1), is $1.54 \mathrm{mAU} \mu \mathrm{mol}^{-1} \mathrm{~L}$, and the detection limit is $<2 \mu \mathrm{mol} \mathrm{L}{ }^{-1}$ (ISO 8466-1, 1990). Other performances are, similarly, better at $466 \mathrm{~nm}$ than at the other wavelengths.

Table 1 : Standardization characteristics at $466 \mathrm{~nm}$ compared with 430 and $456 \mathrm{~nm}$.

\begin{tabular}{lccc}
\hline Data & $\mathbf{4 6 6} \mathbf{~ n m}$ & $\begin{array}{c}\text { Wavelength } \\
\mathbf{4 3 0 ~} \mathbf{~ m m}\end{array}$ & $\mathbf{4 5 6} \mathbf{~ n m}$ \\
\hline $\begin{array}{l}\text { Sensitivity at } 20^{\circ} \mathrm{C} \mathrm{mAU} \mu \mathrm{mol}^{-1} \mathrm{~L} \\
(\text { light path }=1 \mathrm{~cm})\end{array}$ & 1.54 & 4.45 & 2.15 \\
Limit of linearity $\mu \mathrm{mol} \mathrm{kg}$ & & & \\
Measurement uncertainty $\mu \mathrm{mol} \mathrm{kg}$ & $>900$ & 180 & 270 \\
$\left(95 \%\right.$ CL at half-range $\left.0-450 \mu \mathrm{mol} \mathrm{kg}^{-1}\right)$ & \pm 2.7 & \pm 6.7 & \pm 4.0 \\
Limit of detection $\mu \mathrm{mol} \mathrm{kg} \mathrm{ka}^{-1}$ & & & \\
Limit of quantification $\mu \mathrm{mol} \mathrm{kg}^{-1 \mathrm{~b}}$ & 1.8 & 4.5 & 2.7 \\
\hline
\end{tabular}

${ }^{a}$ Limit of detection (LOD) is calculated on the parameters of the calibration curve (ISO 8466-1 standard, 1990).

${ }^{\mathrm{b}}$ Limit of quantification (LOQ) is LOQ $=3.33 \times$ LOD. 


\subsection{Robustness of the method and influential factors.}

Most of the factors influencing the Winkler determination of DO have been described in the literature, in particular by Carpenter (1965a,b) and Carritt and Carpenter (1966). The following factors, either specific to spectrophotometry or not previously studied, have been assessed as described.

Temperature influences both the $\mathrm{I}_{2}-\mathrm{I}_{3}{ }^{-}$equilibrium, and the value of the molar absorptivities. At sea, we actually noticed variations of sample and standard absorbances which were attributed to ambient temperature variations. Consequently, we checked it in the usual laboratory temperature range of 18 to $23^{\circ} \mathrm{C}$.

Reagent volumes should normally be added in accurate amounts in the samples in the optimized procedure of Carpenter (1965b). However, for practical reasons, some variation can be noted among methods, generally because of variable sample flask volumes but fixed reagent volume to be delivered. Since the $\mathrm{I}_{2} / \mathrm{I}_{3}{ }^{-}$proportion depends on the amount of iodide introduced by reagent 2, spectrophotometric results may be influenced by variations in reagent volumes to a greater extent than those from the titration method. Variation reagents of volumes was checked in the range 0.8 to $1.2 \mathrm{~mL}$ in $147 \pm 0.5 \mathrm{~mL}$ sample flasks.

Storage of fixed samples (i.e. with R1 + R2) may be necessary, either for operational reasons, or as a recourse in case of material failure. Beyond one day, it is recommended to store samples under water, to avoid neck drying (Grasshoff, 1962; Riley et al., 1975; Aminot, 1983), but no experiment has been published on that technique. So, a test over a period of 3 days has been included in our experiments.

Our experimental design was logically a $2^{3}$ design, with centered points and one repetition (24 experiments). The 24 samples were withdrawn from an homogenous $30 \mathrm{~L}$ sea water bulk, at steady temperature $\left( \pm 0.01{ }^{\circ} \mathrm{C}\right)$, saturated in dissolved oxygen by continuous bubbling. Table 2 presents the studied factors and their domain, and Table 3 the corresponding absorbances. The multiple linear treatment led to the following model:

$$
\mathrm{A}=0.3596+0.0017 . \text { temp }-0.0004 . \text { volr }+0.0001 \text {.days, }
$$

With $\mathrm{A}=$ measured absorbance, temp $=$ temperature in ${ }^{\circ} \mathrm{C}$, volr $=$ reagent volume and days $=$ number of days of storage.

The multiple linear regression model parameters and variances are summarized in Table 4. Effects of factors on absorbance are illustrated in Figure 2.

Table 2. Factors studied and their levels.

\begin{tabular}{lccc}
\hline Level for X & $\begin{array}{c}\text { Factor 1 : } \\
\text { Temperature of } \\
\text { measurement } \\
\text { (temp) }\end{array}$ & $\begin{array}{c}\text { Factor 2 : } \\
\text { Volume of reagents } \\
\text { (volr) }\end{array}$ & $\begin{array}{c}\text { Factor 3 : } \\
\text { Storage time } \\
\text { D (days) }\end{array}$ \\
\hline-1 & 18 & 0.8 & 1 \\
0 & 20.5 & 1 & 2 \\
+1 & 23 & 1.2 & 3 \\
\hline
\end{tabular}

Only the temperature coefficient is statistically significant. Temperature variations explain $94.5 \%$ of absorbance variations. A temperature difference of $\pm 1^{\circ} \mathrm{C}$ is responsible of a variation of $\pm 1.1 \mu \mathrm{mol} \mathrm{L} \mathrm{L}^{-1}$ in oxygen concentration, i.e. 
$\pm 0.5 \%$ at the experimental concentration $\left(223 \mu \mathrm{mol} \mathrm{L}^{-1}\right)$. Although most authors seem unaware of the temperature effect, our results agree with those of Roland et al. (1999) and we confirm their recommendation to standardize and analyze samples at the same temperature to improve reliability. However, since the equilibrium constant (1) strongly depends on temperature (Carritt and Carpenter, 1966), the effect will be minimized at an isobestic point where the measure is independent of $\mathrm{I}_{2}$ and $\mathrm{I}_{3}{ }^{-}$ proportions.

Tableau 3. Levels of factors and experimental response in absorbance unit (AU).

\begin{tabular}{lcccc}
\hline & Factor 1 X1 & Factor 2 X2 & Factor 3 X3 & Y response \\
\hline 1 & -1 & 1 & -1 & 0.3554 \\
2 & 0 & 0 & 0 & 0.3589 \\
3 & 1 & -1 & -1 & 0.3637 \\
4 & -1 & -1 & 1 & 0.3569 \\
5 & 0 & 0 & 0 & 0.359 \\
6 & -1 & -1 & -1 & 0.355 \\
7 & -1 & 1 & 1 & 0.3559 \\
8 & 1 & 1 & 1 & 0.3641 \\
9 & 1 & 1 & -1 & 0.3645 \\
10 & 0 & 0 & 0 & 0.3587 \\
11 & 0 & 0 & 0 & 0.3586 \\
12 & 1 & -1 & 1 & 0.3641 \\
13 & -1 & 1 & -1 & 0.3551 \\
14 & 0 & 0 & 0 & 0.3591 \\
15 & 1 & -1 & -1 & 0.3654 \\
16 & -1 & -1 & 1 & 0.3569 \\
17 & 0 & 0 & 0 & 0.3579 \\
18 & -1 & -1 & -1 & 0.3554 \\
19 & -1 & 1 & 1 & 0.3557 \\
20 & 1 & 1 & 1 & 0.3641 \\
21 & 1 & 1 & -1 & 0.3646 \\
22 & 0 & 0 & 0 & 0.3584 \\
23 & 0 & 0 & 0 & 0.3591 \\
24 & 1 & -1 & 1 & 0.3634 \\
\hline
\end{tabular}

Tableau 4. MLR results and Student's test on factors.

\begin{tabular}{lccccc}
\hline Parameter & Coefficient & $\begin{array}{c}\text { Standard } \\
\text { deviation }\end{array}$ & Student's $\boldsymbol{t}$ & Confidence \% & Risk \% \\
\hline Constant & 0.3251 & 0.0022 & 146.2591 & 100 & 0 \\
temp & 0.0017 & 0.0001 & 18.7103 & 100 & 0 \\
vol & -0.0004 & 0.0011 & -0.3875 & 29.75 & 70.25 \\
day & 0.0001 & 0.0002 & 0.5536 & 41.4 & 58.6 \\
\hline
\end{tabular}

Varying reagent volume by a factor 1.5 had no statistical influence on the spectrophotometric measurement of iodine, which is attributed to the measurement of the $\mathrm{I}_{2} / \mathrm{I}_{3}^{-}$mixture. The spectophotometric method measures concentrations while titration measures absolute quantities of iodine, hence the dilution generated by the reagents may have greater importance. Computation of the dilution factors indicate a $<0.3 \%$ bias when the reagent volume changed from 0.8 to $1.2 \mathrm{~mL}$ in $147 \mathrm{~mL}$ flasks. Although minor this bias is corrected in the results calculation formula. Dilutions also vary if sample flasks differ in volume, despite constant reagent addition. In that 
case, the bias does not exceed $0.03 \%$ for a $5 \%$ flask volume change, which is negligible with regard to the result precision.

The storage time of up to three days did not statistically influence the results.

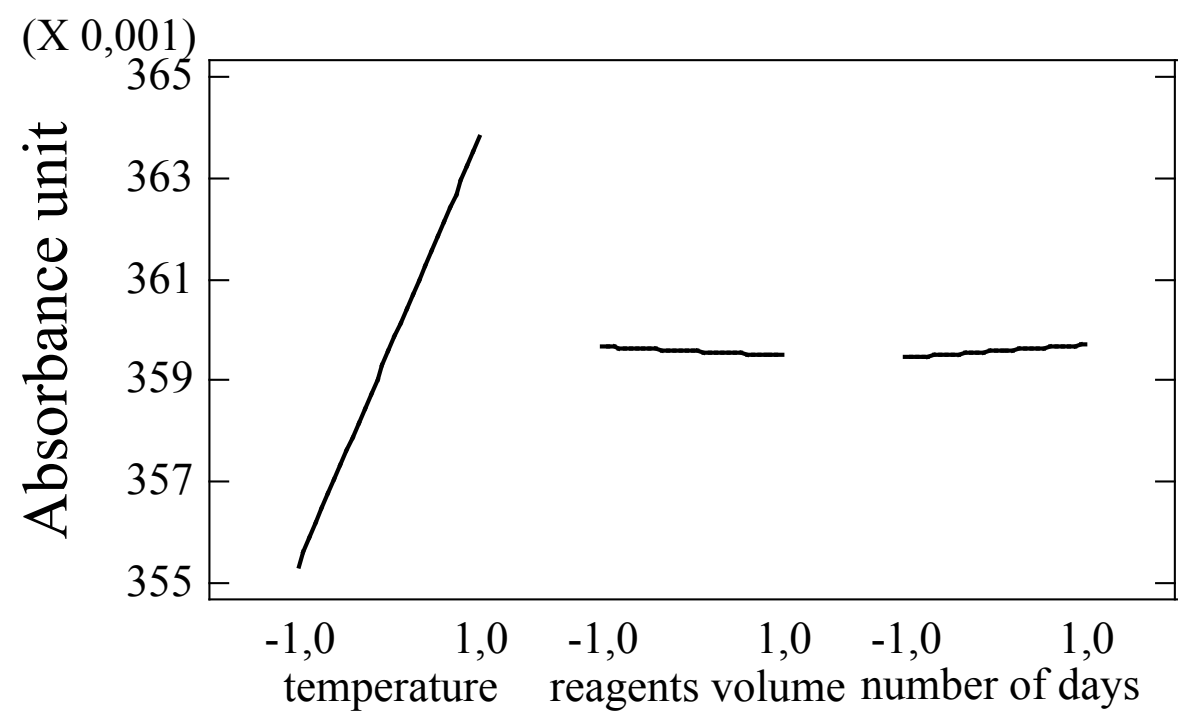

Figure 2. Effect of factors at $466 \mathrm{~nm}$.

Secondary factors have not been checked, such as salinity. Morel, 1965 showed that no significant salt effect could be detected at $466 \mathrm{~nm}$, so standardization could be done in fresh water as recognized by Carpenter (1965b). The presence of particles (turbidity, chlorophyll) or colored substances in the water that might alter the results have already been studied (Pai et al., 1993; Roland et al., 1999). These effects remain minor but have to be checked in extreme environments if necessary.

\subsection{Precision and accuracy}

Precision was determined from 30 samples of homogenous distilled water, withdrawn from a tank aerated 12 hours at $18.8{ }^{\circ} \mathrm{C}\left(291 \mu \mathrm{mol} \mathrm{kg}{ }^{-1}\right)$. Samples were stored underwater and analyzed over 10 consecutive days (three samples each day). Variance homogeneity was checked by a Cochran test (95\% confidence level) (ISO $5725-2,1994)$. This experiment indicated an inter-sample repeatability of $0.45 \%$ and a reproducibility of $0.73 \%$.

The repeatability of 12 samples taken from 12 Niskin bottle closed at the same immersion at sea was $0.12 \%$ at $170 \mu \mathrm{mol} \mathrm{L}^{-1}$ level.

Accuracy of DO determination was checked using the results of the robustness experimental design in which temperature could be measured with a more accurate, calibrated thermometer. The theoretical concentration of oxygen in the sampled water for the experiment design was $223.14 \mu \mathrm{mol} \mathrm{kg}^{-1}$ according to Benson and Krause (1984). The $95 \%$ confidence interval of our result average for the centered points in the experimental scheme $\left(222.73-223.38 \mu \mathrm{mol} \mathrm{\textrm {kg } ^ { - 1 }}\right)$ bracketed the 
theoretical value. The present method can thus be considered unbiased within the obtained precision.

\subsection{Comparison of spectrophotometric and titration DO determination}

During the ARCANE 97 cruise (SHOM - IFREMER Project), in the North East Atlantic, two deep hydrological stations were sampled in the Bay of Biscay (station $77: 44.5^{\circ} \mathrm{N}-03.59^{\circ} \mathrm{W}$ and station $87: 44.5^{\circ} \mathrm{N}-03.20^{\circ} \mathrm{W}$ ). DO was sampled and measured on board in parallel by two teams. The spectrophotometric method described above was compared with an automatic titration method which strictly followed the WOCE (1991) protocol, closely corresponding to the optimized version of Carpenter (1965b).

Figure 3 shows DO concentration profiles of one station. Pooled data from the two stations (60 samples) show that averages and variances of the results from the two methods were homogenous ( $F$ test and Student test at the $95 \%$ confidence level). Averages and variances of the differences between the two methods were homogenous ( $F$ test and Student test at the $95 \%$ confidence level). The average difference between the two methods was $1.0 \pm 1.2 \mu \mathrm{mol} \mathrm{kg} \mathrm{kg}^{-1}$ in the concentration range 190-255 $\mu \mathrm{mol} \mathrm{kg}$. These totally independent determinations indicate good agreement between the two methods and show that spectrophotometry does not bias the results. Furthermore, 30 samples were analyzed in $30 \mathrm{~min}$ by spectrophotometry instead of $2-3$ hours by titration.

Spectrophotometry, applied to the Winkler determination of dissolved oxygen, may therefore be a satisfactory alternative method to replace titration in most cases.

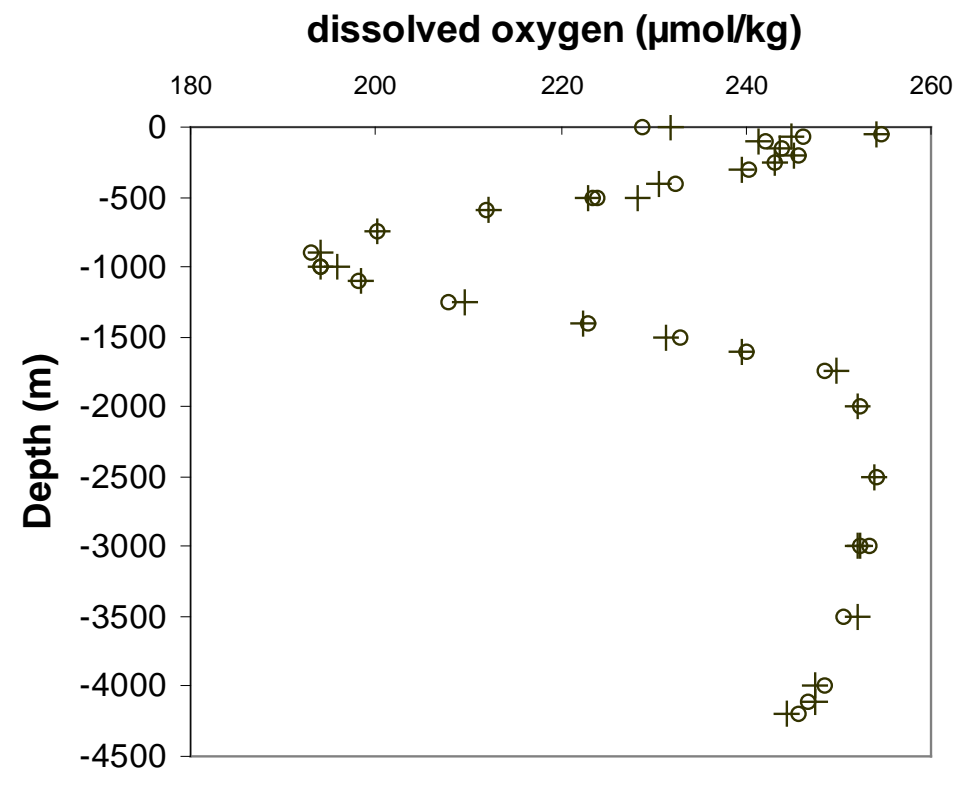

Figure 3. Dissolved oxygen profile at the station 77, during ARCANE 97 cruise. + : spectro at $466 \mathrm{~nm}, 0$ : WOCE IFREMER method.

\section{CONCLUSION}

Spectrophotometry is a valid alternative for accurate and precise determination of dissolved oxygen in waters. Provided a performing spectrophotometer is used, and 
measurements are done at the isobestic point wavelength $466 \mathrm{~nm}$, it allows

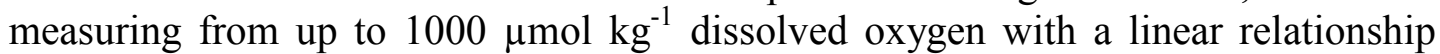
between absorbance and concentration. This range covers all natural waters concentrations in oceanic, coastal and freshwater domains. The main precaution is to standardize and measure samples at the same temperature (about $\pm 1{ }^{\circ} \mathrm{C}$ ). The spectrophotometric method, fast and easy to use on board a ship, is convenient for large series of samples such as those collected from deep oceanic profiles.

\section{Acknowledgements}

The authors are also greatful to Alain Serpette (SHOM) and Bernard Le Cann (IFREMER) for the organization of ARCANE project. The authors would also like to thank André Billant and Pierre Branellec from IFREMER for their collaboration to the intercomparison exercise.

\section{REFERENCES}

AFNOR, 1999. Norme ISO 5813, Qualité de l'eau - Dosage de l'oxygène dissous - Méthode iodométrique. Qualité de l'eau, Tome 2, p. 79-84.

Aminot, A., 1983. Dosage de l'oxygène dissous, in Manuel des analyses chimiques en milieu marin. IFREMER-Brest, 75-92.

Aminot, A., 1988. Precision and accuracy of dissolved oxygen measurements. A comment on the paper by Oudot et al.: precise shipboard determination of dissolved oxygen (Winkler procedure) for productivity studies with a commercial system. Limnol. Oceanogr. 33 (6, part2), 1646-1648.

Analytical Methods Commitee, 1994. Is my calibration linear? Analyst 119, 2363-2366.

Ashton, P.J., Twinch, A.J., 1985. An assessment of a rapid convenient spectrophometric adaptation of the Winkler procedure for the determination of dissolved oxygen in fresh waters. J. Limnol. Soc. Sth. Afr. 11, 62-65.

Awtrey, A.D., Connick, R.E., 1951. The absorption spectra of $\mathrm{I}_{2}, \mathrm{I}_{3}{ }^{-}, \mathrm{I}^{-}, \mathrm{IO}_{3}{ }^{-}$, $\mathrm{S}_{4} \mathrm{O}_{2}{ }^{-}$and $\mathrm{S}_{2} \mathrm{O}_{3}{ }^{2-}$. Heat of the reaction $\mathrm{I}_{3}{ }^{-}=\mathrm{I}_{2}+\mathrm{I}^{-}$. J. Amer. Chem. Soc. 73, 18421843.

Benson, B.B., Krause Jr., D., 1984. The concentration and isotopic fractionation of oxygen dissolved in freshwater and seawater in equilibrium with the atmosphere. Limnol. Oceanogr. 29 (3), 620-632.

Broenkow, W.W., Cline, J.D., 1966. Colorimetric determination of dissolved oxygen at low concentrations. Limnol. Oceanogr. 14, 450-454.

Bryan, J.R., Riley, J.P., Williams, P.J. Le B., 1976. A Winkler procedure for making precise measurements of oxygen concentration for productivity and related studies. J. Exp. Mar. Biol. Ecol. 21, 191-197.

Burger, J.D., Liebhafsky, H.A., 1973. Thermodynamic data for aqueous iodine solutions at various temperatures. Anal. Chem. 45, 600-602.

Carpenter, J.H., 1965a. The accuracy of the Winkler method for dissolved oxygen analysis. Limnol. Oceanogr 10, 135-140. 
Carpenter, J.H., 1965b. The Chesapeake Bay Institute technique for the Winkler dissolved oxygen method. Limnol. Oceanogr. 10 (1), 141-143.

Carrit, D.E., Carpenter, J.H., 1966. Recommendation procedure for Winkler analyses of sea water for dissolved oxygen. J. Mar. Res., 24, 313-318.

Cluster, J.J., Natelson, S., 1949. Spectrophotometric determination of microquantities of iodine. Anal. Chem. 21, 1005-1009

Duval, W.S., Brockington, P.J., Von Melville, M.S., Geen, G.H., 1974. Spectrphotomatric determination of dissolved oxygen concentration in water. J. Fish. Res. Board Can. 31, 1529-1530.

Grasshoff, K., 1962. Untersuchungen über die Sauerstoffbestimmung im Meerwasser. Kieler Meeresforsch., 18, 42-50.

Green, E.J., Carrit, D.E., 1966. An improved iodine determination flask for whole-bottle titration. Analyst 91, 207-208.

ISO 5725-2, 1994. Basic method for the determination of repeatability and reproducibility of a standard measurement method.

ISO 8466-1, 1990. Water quality - Calibration and evaluation of analytical methods and estimation of performance characteristics - Part 1: Statistical evaluation of the linear calibration function.

Knapp, G.P., Stalcup, M.C., Stanley, R.J., 1991. Iodine losses during Winkler titrations. Deep-Sea Res. 38, 121-128.

Mackereth, F.J.H., Heron, J., Talling, J.F., 1978. Water analysis : some revised methods for limnologist. Scientific Publication - Freshwater Biological Association, vol. 36. Titus Wilson and Son, Kendal.

Millard, R.C., 1991. CTD oxygen calibration procedure. US WOCE Hydrographic Program Report WHPO 91-1, (27 pp.)(WOCE Report No. 68/91).

Morel, A., 1965. Mise au point d'une méthode spectrophotométrique pour le dosage de l'oxygène dissous dans les eaux de mer. Bull. Inst. Océanogr. Monaco 64 (1332), 1-31.

Murray, C.M., Riley, J.P., Wilson, T.R.S., 1968. The solubility of oxygen in Winkler reagents used for the determination of dissolved oxygen. Deep-Sea Res. 15, 237-238.

Pai, S.C., Gong, G.C., Liu, K.K., 1993. Determination of dissolved oxygen in seawater by direct spectrophotometry of total iodine. Mar. Chem. 41, 343-351.

Riley, J.P., Robertson, D.E., Dutton, J.W.R., Mitchell, N.T., Williams, P.J. Le B., 1975. Analytical chemistry of sea water. In: Riley, J.P., Skirrow, G. (Eds), 2nd ed. Chemical Oceanography, vol. 3, pp. 193-514.

Roland, F., Caraco, N.F., Cole, J.J, Del Giorgio, P., 1999. Rapid and precise determination of dissolved oxygen by spectrophotometry : evaluation of interference from color and turbidity. Limnol. Oceanogr. 44, 1148-1154.

WOCE, 1991. Operations manual, the observation program Section 3.1. WOCE Report No 68/91. 